\title{
Professional practice of nurses and influences on moral sensitivity
}

How to cite this article: Moreira DA, Ferraz CMLC, Costa IP, Amaral JM, Lima TT, Brito MJM. Professional practice of nurses and influences on moral sensitivity. Rev Gaúcha Enferm. 2020;41:e20190080. doi: https://doi. org/10.1590/1983-1447.2019.20190080 a Escola Técnica Sandoval Soares de Azevedo. Ibirité, Minas Gerais, Brasil.

- Universidade Federal de Minas Gerais (UFMG), Escola de Enfermagem. Belo Horizonte, Minas Gerais, Brasil.

\section{ABSTRACT}

Objective: To understand the professional practice of nurses and their influence on the development of moral sensibility.

Methods: A qualitative and descriptive study, conducted between November 2015 and February 2016 in the hospitalization units of the medical clinic of two large hospitals located in Belo Horizonte, Minas Gerais. 14 nurses participated. Data collection was done through interviews, guided by semi-structured scripts. The data were submitted to content analysis.

Results: Two categories emerged: Professional practice of the nurse: internal and external goods and Moral sensitivity and the interface with the professional practice of nurses. The development of the moral sensitivity of nurses is influenced by factors related to professional practice, such as interpersonal relations, ethical education and management activities.

Final considerations: In the professional practice, moral sensibility is an integral part of the ethical decision-making process in services, being essential for quality care.

Keywords: Ethics, nursing. Morale. Professional practice.

\section{RESUMO}

Objetivo: Compreender a prática profissional do enfermeiro e suas influências para o desenvolvimento da sensibilidade moral. Métodos: Estudo qualitativo, descritivo, realizado entre novembro de 2015 e fevereiro de 2016, em unidades de internação da clínica médica, de dois hospitais de grande porte, localizados em Belo Horizonte, Minas Gerais. Participaram 14 enfermeiros. A coleta de dados ocorreu por meio de entrevistas, guiadas por roteiros semiestruturados. Os dados foram submetidos à análise de conteúdo.

Resultados: Emergiram duas categorias: Prática profissional do enfermeiro: bens internos e externos e; Sensibilidade moral e a interface com a prática profissional de enfermeiros. 0 desenvolvimento da Sensibilidade moral dos enfermeiros, sofre influência de fatores relacionados à prática profissional, como as relações interpessoais, a educação ética e as atividades de gestão.

Considerações finais: Na prática profissional, a Sensibilidade moral é parte integrante do processo de tomada de decisão ética nos serviços, sendo essencial para o cuidado de qualidade.

Palavras-chave: Ética em enfermagem. Moral. Prática profissional.

\section{RESUMEN}

Objetivo: Comprender la práctica profesional de la enfermera y su influencia en el desarrollo de la Sensibilidad moral.

Métodos: Estudio cualitativo y descriptivo realizado entre noviembre de 2015 y febrero de 2016 en unidades de internación de la clínica médica de dos hospitales de gran porte, ubicados en Belo Horizonte, Minas Gerais. Participaron 14 enfermeras. La recolección de datos se efectuó por medio de entrevistas, guiadas por guiones semiestructurados. Los datos se sometieron a análisis de contenido. Resultados: Surgieron dos categorías: Práctica profesional de la enfermera: bienes internos y externos y Sensibilidad moral y la interfaz con la práctica profesional de las enfermeras. El desarrollo de la sensibilidad moral de las enfermeras sufre la influencia de factores relacionados con la práctica profesional, como las relaciones interpersonales, la educación ética y las actividades de gestión. Consideraciones finales: En la práctica profesional, la Sensibilidad moral es parte integrante del proceso de toma de decisiones éticas en los servicios, siendo esencial para un cuidado de calidad. Palabras clave: Ética en enfermería. Moral. Práctica profesional. 


\section{口INTRODUCTION}

The professional practice is a social activity, based on principles of cooperation between individuals who assume differentiated roles. To this practice is incorporated the ethical knowledge, understood as guidelines for a just life, which are based on moral, through reflections of social activities that acquire meanings in the individual and collective sphere ${ }^{(1)}$. Regarding nursing, understanding its practice means surpassing the technical-operative dimensions resulting from the direct application of biotechnological knowledge.

From this perspective, we looked at the singularities of the practice of nurses working in inpatient units of the medical clinic. Inpatient units are characterized as dynamic, multi-professional, with case diversity and intended for multiple care. Such factors contribute to triggering ethical work problems, with consequences for staff and users.

Ethical problems are related to ethical aspects or implications, present in the practice of health professionals and mobilize moral reflection, causing the individual to question himself and the situation experienced ${ }^{(2)}$. Such problems arise when the rules established and the technically routinized actions do not correspond to the ideals of the workers and when conflicts of personal and professional values occur between the actors involved ${ }^{(3)}$. The experience of ethical problems is a challenge for the performance of nurses, as it demands critical thinking, confidence and courage, essential characteristics for decision making and moral sensitivity ${ }^{(4-5)}$.

In order to achieve the objective of this research, emphasis was placed on moral sensitivity, which stands out for its dynamism and dependence on moral experience, experienced in professional practice, through its relationship with others and self-recognition ${ }^{(6)}$.

For the purposes of this study, moral sensitivity is understood as the set of attributes that enable professionals to make ethical decisions with intelligence and compassion, in view of the patient's physical, emotional and spiritual needs and the uncertainties surrounding care. Such attributes include skills, sensations, feelings and moral knowledge, which allow professionals to perform better on the ethical problems present in their work environment ${ }^{(7-8)}$.

For the above reasons, the following is asked: How is the professional practice of nurses and how does this practice influence the development of moral sensitivity?

Despite the relevance of this theme, there are still few studies devoted to its approach with nurses. Therefore, investigations that deepen this theme become relevant, favoring ethical practice and as a stimulus to the development of moral sensitivity of nurses.
It is hoped that the results of this study may prompt the search for the construction of work environments that value the professional practice of nurses, contributing to the development of their moral sensitivity. Considering the above, this study aimed to: understand the professional practice of nurses and their influences on the development of moral sensitivity.

\section{METHODOLOGY}

This is a descriptive study of a qualitative approach, conducted in inpatient units of a medical clinic of two large and special public hospitals that provide exclusive care to patients of the Unified Health System (Sistema Único de Saúde, SUS) located in Belo Horizonte, Minas Gerais, Brazil. Hospitals play a relevant role in assisting clinical and surgical emergencies, providing care to patients from various municipalities in the metropolitan region of Belo Horizonte. Regarding the number and destination of beds, one of the hospitals, during the investigation period, had 323 general beds, of which 150 were intended for medical clinic inpatient units; the other hospital had 901 general beds, of which 479 were beds of inpatient units of a medical clinic.

Sampling was non-probabilistic for convenience. All the nurses who worked in the inpatient units of the medical clinic during the day shift were invited and agreed to participate in the study, totaling 14 nurses. As inclusion criteria, it was considered the fact that the professional works in the medical clinic units selected for the study and was available to participate in the interview. The exclusion criteria were defined as being on vacation, away or on leave.

Data collection took place between November 2015 and February 2016, through recorded interviews, guided by a semi-structured script, conducted individually, in the workplace and in a private setting. The mean duration of the interviews was 17 minutes. The guiding questions were the following: What does being a nurse mean to you? Talk about your professional practice at the hospital. Talk about the ethical problems you experience in your daily work. Report a situation that involves ethical issues in your work. Report a work situation in which you have opted for a decision contrary to your desire/ethical judgment.

The data were fully transcribed and subsequently submitted to content analysis, which consists of a set of techniques that allow the researcher to relate and confer meanings of linguistic, psychological or sociological structures. This analysis included the pre-analysis stages, in which the organization and floating and exhaustive reading of the material takes place; exploration, phase in which the coding and 
categorization of data takes place; and treatment of the results, which consists of making inferences and interpretations of the data by the researcher ${ }^{(9)}$.

The research was approved by the Research Ethics Committee of the Federal University of Minas Gerais, according to opinion No.1,237,831 on September 21 ${ }^{\text {th }}$, 2015. The participants signed the Free and Informed Consent Form, according to Resolution 466/2012 of the National Health Council. To ensure anonymity, we chose to identify the statements with a letter (E), followed by the number established for each interview.

\section{口ESULTS AND DISCUSSION}

The study participants were female, with a mean age of 33.5 years old. Regarding marital status, 50\% were single, $35.8 \%$ married and $14.2 \%$ divorced. The time of training ranged from 1 to 23 years, and $57.1 \%$ had a specialization degree. As for the workload $71.4 \%$ worked from 8 to 10 hours a day and $21.4 \%$ had more than one job.

The following analytical categories emerged from data analysis: Professional practice of nurses: internal and external assets and; Professional practice of nurses and the interface with moral sensitivity.

\section{Professional practice of nurses: internal and external assets}

Practice is the action of humans over things and involves the application of knowledge in practical situations, targeted for a particular purpose. In the context of professional practice, the purpose is to achieve internal and external assets. Internal assets provide meaning and social legitimacy to the professions, giving them rationality. External assets, on the other hand, are common to most activities and do not lend themselves to specifying or distinguishing them ${ }^{(10)}$.

In transposing the meaning of practice into the field of nursing, it is assumed that its internal asset is translated as care, with a view to providing improvements for the health of individuals ${ }^{(11)}$

Being a nursing professional is knowing how to care, being responsible for caring, and as we work with a team, you have to be a responsible person for the human being in general. (E1).

The practice in nursing has as its object human health, seeking to transform it, intentionally and planned carefully, through means and instruments ${ }^{(10)}$. The achievement of the internal asset demands from nurses the adoption of principles, values, technical skills and ethics, in order to create a work environment permeated by co-responsibility and acceptance. For this, professionals need to be sensitive to assisted patients, as well as political engagement in the transformation of inequalities ${ }^{(12)}$.

The concern in providing a quality care was expressed by the participants. However, barriers that interfere with the quality of care were highlighted.

The workload of any institution for the nurse is large, so sometimes we try to do a higher quality work, but due to other attributions, through other nursing processes, ends up compromising the best patient care. (E2)

Sometimes we don't have a lot of time to evaluate the patient well, to listen, to be able to make an anamnesis, a physical exam, because we focus in the bureaucratic issue, in the rush of everyday life, so the other side of nursing ends up being a little on the side. The routine is tiring, it's busy, a lot to do in a short time. (E3)

The challenges faced by nurses interfere with the performance of professional activity and on quality of life. In addition, work overload potentiates health problems and feelings of frustration ${ }^{(13)}$.

A research study that sought to evaluate the professional practice environment and burnout levels among nursing professionals of a teaching hospital in São Paulo showed that subscale, autonomy and control are predictors of emotional exhaustion, depersonalization and diminished personal fulfillment ${ }^{(14)}$. Another study identified the values that structure and guide nursing as a social practice, revealing that failures in the organization of services and in the health production process represented obstacles to the implementation of important ethical references for nursing care ${ }^{(12)}$.

The present study revealed that the inadequate conditions for work development subvert nursing as a professional practice, making that the purpose of meeting the needs of patients is not reached. In this perspective, when the inner asset is not achieved, the practice lacks sense. Concerning the external asset of a profession, this is obtained when the legitimate professional practice is carried out. As external assets, money, prestige and power ${ }^{(1)}$ are cited.

The statements made it possible to identify that external assets are of less relevant to nurses, and are less valued than internal assets. 
When you choose to be a nurse you can't think about money, in any of that, social status [...] you are doing it because you like to have contact with the patient [...] you're doing it for love, because you are not well recognized, you face many adversities, obstacles [...] when there is no more love, no more passion, then leave it, because otherwise you start doing things in the wrong way and the patient does not deserve it, because the first contact that the patient has [...] daily and for 24 hours is with the nurse, the doctor evaluates, if you need, you call him, but it is the nurse who is beside the patient. (E4)

A research study developed with professionals from inpatient units of a general hospital presented in a prominent position the scope of nursing internal assets. The care activities were associated with a sense of pride and self-fulfillment and were considered important in promoting recognition and job satisfaction ${ }^{(13)}$.

It is important to emphasize that the professionals need to aim for the achievement of the internal asset and of the external assets. However, when the workers dedicate themselves solely to the conquest of external assets, the profession becomes distorted ${ }^{(1)}$.

It is considered essential that the institutions provide nurses with working conditions that cooperate to achieve a professional practice that integrates internal and external assets. This integration is considered fundamental because it contributes to the achievement of professional fulfillment and qualified and resolute care.

\section{Professional practice of nurses and the interface with moral sensitivity}

As a practice, nursing is subjected to transformations and to the incorporation of reflections and actions on new themes and problems, being guided by ethical principles linked to the maintenance or restoration of dignity in different areas of life. Thus, the nursing practice can culminate in situations of tension and conflicts of ethical values, in view of interpersonal relationships ${ }^{(8)}$.

In this study, nurses reported the difficulty in dealing with inappropriate comments from other colleagues and/ or professionals in the presence of patients.

Some wrong comments maybe in front of a patient, I think this is a difficulty that we have to work on with the team. It is an attitude in front of this patient, is how you approach, how you present. (E2)

The ethical, unfortunately in health, I don't say it is even in this hospital, but in health in general, people talk about the mistakes of others, nobody talks about their own mistakes. (E1)

The obstacles faced by the nurses in interpersonal relationships require the development of personal capacity to deal with ethical dilemmas inherent in relationships. For this, the development of moral sensitivity becomes indispensable ${ }^{(8)}$.

Moral sensitivity is a premise for understanding the ethical problems that occur in health services and for properly addressing these issues ${ }^{(8)}$. The greater the moral sensitivity of nurses is, more ethical is their professional practice ${ }^{(10)}$.

In this sense, several studies show that the moral sensitivity of the individual develops continuously, according to the formation and experiences of professional practice ${ }^{(15)}$. Therefore, a comprehensive and interactive perception on social and health issues is necessary, in line with the complexity of these areas and the pluralities of society ${ }^{(12)}$. In the same vein, the research has broadened the concept of moral sensitivity and encompassed dimensions other than cognitive ability, including sensations, feelings, moral knowledge, and abilities ${ }^{(1)}$.

Moral sensitivity can be developed when the professional faces a delicate case that generates uncertainties in the provision of care. It therefore embraces the ability to make ethical decisions with intelligence and compassion for the patient's physical, emotional and spiritual needs ${ }^{(8)}$.

There was a time when we had an inmate and I don't know how the girls heard that this patient had killed his wife, abused his daughter and I had an employee who was once abused. So, I think she saw in that patient the person who did this to her [...] she didn't want to administer medication, she didn't want to give care. I understood her situation a little, so I changed the schedule of work. But I saw that the whole team changed the way of treatment and as much as I talked, I saw that there was a change regardless of what that patient did, we have to look at him as a human being that we have to take care and I had to change my whole schedule. This was a different form of conduct. (E5)

We have to respect a lot the patient's belief. These days we had a patient who was a Jehovah's Witness with a severe anemia, but lucid, oriented. The doctor brought to the station, explained the situation, she had to undergo surgery and she did not want to. She called a relative. It was like this, the comment of a technician: "Just give her some medicine for her to sleep and she'll get out of this." Like, she will improve from this anemia. So, I called these employees and said: "Look, we can never do that." We get in contact with the legal personnel who guide us a lot about religion. We can never give a drug to cause the patient to 
sleep and administer. None of this we can do because it is unethical and it is her religion. (E6)

The statements revealed experiences of ethical conflicts, due to the decisions that permeate the subjectivity of professionals and respect for the rights and autonomy of patients in relation to the care provided. We highlight the importance of vocational training focused on the development of skills that enable nurses to mobilize and articulate knowledge and values in their daily work. The relation between ethics, moral sensitivity and competences is little discussed in the various scenarios of nurses' performance, and strategies to expand or develop their dimensions are not explored ${ }^{(8,16)}$.

It is noteworthy that in hospitalization units, the reflections, made possible by the experiences, allow nurses to improve skills that help in the development of moral sensitivity. Such process occurs continuously and contemplates the relationship with other professionals, enabling the articulation between learning, knowledge and awareness ${ }^{(8,17)}$.

This / find very important, knowing how to raise a problem. You don't have to lower anyone, you have to be polite, when pointing the problem of a nursing technician, you call him in a room and points his problem alone, from my coordinator with me, I think it has to be the same way. (E1)

I think everyone in the workplace has to have a professional positioning. If you know how to face this with tranquility and when you need to approach whoever is, this must be preserved, with privacy, knowing how to understand the other and even maintain the atmosphere of harmony. (E2)

In addition to the influences of interpersonal relationships and ethical education, nurses considered management activities as obstacles to the development of moral sensitivity, by distancing the professional from the patient.

I think the nurse had to focus more on the patient care part, you end up spending more time with the bureaucratic part than with the patient himself, you don't have much time, right? To provide that qualified care, because here is a nurse for 49, so I think that in this case there should be a nurse for the care part and another for the bureaucratic part, because the nurse who stays here is more focused on the bureaucratic part than in the care part. (E7)

Because I have a lot of bureaucratic things to accomplish, I wish I have more time, for example, my patient who evolves with injury, I wish I have time to better follow this injury. (E5)
In line with the speeches of the participants of this study, a research study conducted with nurses from an adult emergency room of a university hospital revealed the discontent of the professionals with their working conditions, with exhaustive shift hours. In addition, the overload of tasks was highlighted, causing them to perform the work mechanically, for lack of time to evaluate the activities developed, compromising patient care ${ }^{(18)}$.

Another research study also identified the discrepancy between the values relevant to nurses in the scope of their professional practice and the values that guide the work in the institution. In this context, nurses face moral problems, because they have to do bureaucratic work to the detriment of patient care ${ }^{(19)}$.

The development of moral sensitivity demands a relationship with at least one other person, and an ethical relationship results from the mutual understanding between the parties ${ }^{(20)}$. In this sense, it is clear from the reports that the overload of activities, especially the bureaucratic demands, is presented as a factor that interferes with the moral sensitivity of the professionals, as it makes the nurse-patient contact difficult.

In view of the results and the analysis presented, it is highlighted that moral sensitivity comprises the perception of the patient's vulnerabilities and the consequent ethical decision-making by nurses in their favor ${ }^{(8)}$. When the moral sensitivity of nurses is repressed, there is a decharacterization of the practice, negatively affecting the reach of the internal good of the profession.

\section{—FINAL CONSIDERATIONS}

In the professional practice of nurses, moral sensitivity is an integral part of the process of ethical decision-making and is essential for quality care. However, the results of this study revealed that factors such as interpersonal relationships, ethical education, and bureaucratic activities negatively interfere with the development of moral sensitivity of nurses.

It is hoped that the reflections presented in this study may raise discussions with a view to the implementation of strategies that favor the development of the moral sensitivity of nurses, as well as the reach of the profession's internal goods, in order to contribute to qualified and resolute practice.

Thus, the results can help nurses to enhance their moral sensitivity and to exercise an increasingly ethical practice, as well as to warn educational and health institutions about the importance of creation of spaces capable of fostering the discussion of ethical problems that may affect the quality of care 
This study points to the need for further research aimed at understanding the moral sensitivity of nurses in different contexts practices, allowing to generate more representative information on the phenomenon under investigation.

As a limitation of the study, the interviews mentioned are only with nurses who work during the day. In addition, the context in which the study participants are inserted may affect their perceptions, making it impossible for the results presented to be generalized to other scenarios.

\section{口 REFERENCES}

1. Cortina A. Cidadãos do mundo - para uma teoria da cidadania. São Paulo: Loyola; 2005.

2. Dalla Nora CR, Zoboli ELCP, Vieira MM. Moral sensitivity in Primary Health Care nurses. Rev Bras Enferm. 2017;70(2):308-16. doi: https://doi. org/10.1590/0034-7167-2016-045

3. Ramos FRS, Barlem ELD, Brito MJM, Vargas MA, Schneider DG, Brehmer LCDF. Conceptual framewok for the study of moral distress in nurses. Texto Contexto Enferm. 2016;25(2): e4460015. doi: https://doi.org/10.1590/010407072016004460015

4. Lillemoen L, Pedersen R. Ethical challenges and how to develop ethics support in primary health care. Nurs Ethics. 2013;20(1):96-108. doi: https://doi. org/10.1177/0969733012452687

5. Dalla Nora CR, Deodato S, Vieira MMS, Zoboli ELCP. Elements and strategies for ethical decision-making in nursing. Texto Contexto Enferm. 2016;25(2):e4500014. doi: https://doi.org/10.1590/0104-07072016004500 014

6. Ramos FR, Barth PO, Schneider AMM, Cabral AS, Reinaldo JDS. Consequences of moral suffering in nurses: integration review. Cogitare Enferm. 2016;21(2):e45247. doi: https://doi.org/10.5380/ce.v21i2.45247

7. Lutzén K, Dahlquist V, Eriksson S, Norberg A. Developing the concept of moral sensitivity in health care practice. Nurs Ethics. 2006;13(2):187-96. doi: https:// doi.org/10.1191/0969733006ne8370a

8. Nora CRD, Schaefer R, Álvarez ESS, Ramos MDB. Moral sensitivity and related factors: the perception of nurses. Cogitare Enferm. 2016;21(4):e47410. doi: https://doi.org/10.5380/ce.v21i4.47410

9. Bardin L. Análise de conteúdo. 4. ed. rev. ampl. Lisboa: Ediç̄es 70; 2016.

10. Robichaux C. Developing ethical skills: from sensitivity to action. Crit Care Nurse. 2012; 32(2):65-72. doi: https://doi.org/10.4037/ccn2012929
11. Maclntyre A. After virtue: a study in moral theory. $3^{\text {rd }}$ ed. Indiana: Notre Dame Press; 2007.

12. Zoboli ELCP; Schveitzer MC. Nursing values as social practice: a qualitative metasynthesis. Rev Latino-Am Enfermagem. 2013;21(3):695-703. doi: https://doi. org/10.1590/S0104-11692013000300007

13. Duarte JMG, Simões ALA. Meanings of work for nursing professionals in a teaching hospital. Rev Enferm UERJ.2015 [cited 2017 Nov 20];23(3):388-94. Available from: https://www.e-publicacoes.uerj.br/index.php/enfermagemuerj/article/view/ 6756

14. Marcelino CF, Alves DFDS, Guirardello EB. Autonomy and control of the work environment by nursing professionals reduce emotional exhaustion indexes. Rev Min Enferm. 2018;22:e1101. doi: https://doi.org/10.5935/1415-2762. 20180029

15. Baykara ZG, Demir SG, Yaman S. The effect of ethics training on students recognizing ethical violations and developing moral sensitivity. Nurs Ethics. 2015;22(6):661-75. doi: https://doi.org/10.1177/0969733014542673

16. Barlem ELD. Professional training of the nurse and ethical challenges of the profession. Rev Rene. 2014;15(5):731. doi: https://doi.org/10.15253/217567 83.2014000500001

17. Lorenzetti J, Oro J, Matos E, Gelbcke FL. The work of hospital nursing: approaches in the literature. Texto Contexto Enferm, 2014;23(4):1104-12. doi: https://doi. org/10.1590/0104-07072014001510012

18. Miorin JD, Camponogara S, Pinno C, Beck CLC, Costa VFEO. Pleasure and suffering of nursing workers in an emergency room. Texto Contexto Enferm. 2018;27(2):e2350015. doi: https://doi.org/10.1590/0104-070720180002350 015

19. Caram CS, Brito MJM, Peter E. [Hospital accreditation: excellence as a source of moral suffering for nurses]. Enferm Foco. 2019 [cited 2019 Feb 4];1(1):31-5. Portuguese. Available from: http://biblioteca.cofen.gov.br/ wp-content/uploads/2018/08/Acredita\%C3\%A7\%C3\%A30-hospitalar-aexcel\%C3\%AAncia-como-fonte-de-sofrimento-moral-para-enfermeiros.pdf

20. Borhani F, Abbaszadeh A, Mohsenpour M. Nursing students' understanding of factors influencing ethical sensitivity: a qualitative study. Iran I Nurs Midwifery Res. 2013 [cited 2017 Nov 20];18(4):310-5. Available from: https://www.ncbi. nlm.nih.gov/pmc/articles/PMC3872867/

\section{Acknowledgments:}

CAPES, FAPEMIG, CNPq and NUPAE

\title{
- Corresponding author:
}

Danielle de Araújo Moreira

E-mail: danimg12@yahoo.com.br

\author{
Associate editors: \\ Ana Karina Silva da Rocha Tanaka \\ Jéssica Machado Teles
}

Received: 03.04.2019

Editor-in-chief:

Approved: 09.16.2019

Maria da Graça Oliveira Crossetti 